\title{
Protecting Boat People Reply to David Matas
}

\author{
JAMES BISSETT
}

$\mathrm{T}$ he paper by David Matas entitled "Protecting Boat People" is, as he points, out designed to be a criticism of Bill C-4, "Preventing Human Smugglers from Abusing Canada's Immigration Systems Act." He argues the Bill mistreats asylum seekers from Sri Lanka; violates refugee rights; discourages smuggling by punishing the smuggled; is in violation of the Refugee Convention and the Canadian Charter of Rights and Freedoms; and he accuses the Government of using "evasive techniques to prevent a commitment to refugee protection."

The major thrust of his paper is that following the brutal civil war in Sri Lanka which ended almost three years ago in May 2009, the Tamil population there continues to be subject to "systemic discrimination, harassment and persecution ..." by the Sri Lankan government. He argues that since the civil war has ended the "standard refrain" from refugee boards and settlement officers is that protection and settlement is no longer necessary. And he further argues that those Tamils who have found refuge in countries in the region are afraid to go back home.

The UNHCR does not agree with this pessimistic assessment. The latest country profile on the situation in that country reports that since the end of the armed conflict there has been a "steady improvement in security".

The emphasis in UNHCR operations has shifted from humanitarian relief to early recovery and development. By the end of April 2011, the majority of internally displaced $(395,000)$ had returned home and the remainder living with host families is expected to return this year. The improvement in security is expected to increase the number of voluntary return of refugees from abroad, especially from India.

The UNHCR also stresses that humanitarian and protection-related needs of internally displaced people (IDPs) and refugee returnees remain the main priority. It is also actively involved in providing assistance to community development and institution building as well as being the main provider to IDPs and returning refugees. Clearly this report from the UNHCR would indicate the authorities on the ground in Sri Lanka do not support the allegations made by Mr. Matas.

Furthermore, in an extraordinary press briefing in August 2010, a UNHCR spokesman commended the "exemplary work" of the Canadian Border services agency in coordinating the arrival and reception of the MV Sun Sea passengers. He also added that the UNHCR supports the important work of law enforcement agencies in combating human smuggling while at the same time recognizing that refugees and migrants might sometimes use the same means of illegal transportation, refugees are a distinct group with critical protection needs. ${ }^{2}$

He also pointed out that UNHCR had recently issued revised guidelines to assist decision makers in reviewing asylum claims. The guidelines included the recommendation that in view of the improved security situation, claims by asylum seekers from Sri Lanka should be considered on their individual merit rather than on a group basis.

Mr. Matas outlines in some detail the Comprehensive Plan of Action (CPA) adopted by the United Nations at a conference in June 1989 to help resolve the growing problem of people fleeing Vietnam, Cambodia, and Laos in small boats and seeking refuge in neighboring countries with the hope of eventual resettlement in the industrial countries of the West.

Although the Vietnam War ended in 1975 thousands continued to flee creating serious problems for the countries of first asylum. The aim of the CPA was to bring an end to this unregulated flow of people, which was not only threatening to destabilize the region but was causing the death of many of the boat people through loss at sea and at the hands of pirates. 
Mr. Matas describes the plan as having three components: the establishment of refugee screening procedures; the return to their country of origin of those who failed the screening; and resettlement in third countries of those meeting the refugee criteria. People who had arrived prior to the date screening took place were eligible for resettlement without refugee screening.

Obviously the CPA was to bring an end to the exodus of asylum seekers from Indochina. This was confirmed by the chairman of the UN conference in his closing statement, quoted by Mr. Matas, when he said “ ... asylum seekers could no longer assume that they would be automatically regarded as refugees and therefore entitled to automatic resettlement. It was also formulated in the recognition that if developed countries will take people whether refugees or not who are fleeing desperate conditions at home then the law of "if you take them they will come" applies.

It is not clear why Mr. Matas described the CPA in some detail in his paper. He does suggest there were a number of problems with its structure. For example, that the refugee screening was not done by Canadian authorities and thus was an abdication of Canadian sovereignty and that the foreign screening was inadequate but he does not explain why he has reached these conclusions.

Later in the paper he suggests an agreement similar to the CPA between countries of "proximate" refuge and countries of resettlement for Sri Lankan and other refugees in the region would be a more plausible option. He then outlines the three components of his proposal which sound very similar to the CPA-screening to be done by the "proximate" country; those who failed the screening would be returned; and those meeting the refugee criteria would be taken in by resettlement countries. As with the CPA, the UNHCR would be responsible for the management of the program.

Mr. Matas actually put this proposal to the office of the UNHCR in Geneva in an effort to help solve the problem of 87 Sri Lankan asylum seekers aboard the ship MV Elysia which was stopped by Indonesia authorities en route from Malaysia to New Zealand. However, as might be expected, the UNHCR did not accept the idea of another CPA for Sri Lankan asylum seekers.

Although not saying so in his paper, it is obvious that the UNHCR was simply following its current policy with respect to refugee issues: first to find refuge in the country of origin if possible; second, resettlement in a regional neighboring country in the hope of eventual return home if and when conditions permit-and finally, as a last resort, resettlement in a third country.

Mr. Matas seems to take the position that all those who claim refugee status are genuine refugees and those asylum seekers who pay human smugglers thousands of dollars to human smugglers are if they are caught and penalized in any way are victims. This fails to recognize that human smuggling has become a serious international problem and Canada has become a country of choice for this criminal activity because of our generous asylum policy. Bill C-4 is an attempt to curtail this activity, it is not an effort to prevent genuine refugees from gaining Canada's protection.

\section{Notes}

1. See the 2012 UNHCR Country Operations Profile-Sri Lanka (www.unhcr.org/pages/49e4878eb.html)

2. See UNHCR Statement "UNHCR Encouraged by Canada's Handling of Tamil Boat People Case," 17 August 2010, (www.unhcr.org/4cba68ea0.html)

James Bissett is a Distinguished Fellow with the Canadian Centre for Policy Studies. He is the former Canadian Ambassador to Yugoslavia where he served from 1990-1992. He was also Ambassador to Bulgaria and Albania. He had diplomatic postings in the Balkans, London and in the Caribbean where he served as Canadian High Commissioner to Trinidad and Tobago from 1985-1990. He was an Assistant under Secretary for Social Affairs at the Foreign Ministry in Ottawa. From 1985 -1990 Bissett was Director General of the Canadian Immigration Service. Upon leaving the Foreign Service he served from 1992 -1997 as the Chief of Mission for the International Organization for Migration in Moscow helping the government deal with the thousands of Russians returning from the former countries of the Soviet Union. 